\title{
Pengaruh Citra Merek dan Kepercayaan Merek Terhadap Loyalitas Merek Sego Njamoer (Studi pada Gerai Sego Njamoer Foodcourt Royal Plaza Surabaya)
}

\author{
Abdul Ghofur ${ }^{1}$, Supriyono ${ }^{2 *}$ \\ ${ }^{12}$ Program Studi Manajemen, Universitas Pembangunan Nasional "Veteran” Jawa Timur
}

Email : omphieku@gmail.com

DOI : https://doi.org/10.37339/e-bis.v5i2.700

Diterbitkan oleh Politeknik Dharma Patria Kebumen

\section{Info Artikel}

Diterima :

2021-09-20

Diperbaiki :

2021-10-03

Disetujui :

2021-10-09

\begin{abstract}
ABSTRAK
Sego Njamoer merupakan merek makanan cepat saji olahan jamur terpopuler di Surabaya yang sedang mengalami tren fluktuasi penjualan pada gerai Foodcourt Royal Plaza Surabaya. Fluktuasi tersebut dikarenakan turunnya loyalitas merek pelanggan dalam memilih dan membeli makanan Sego Njamoer. Tujuan dari penelitian ini untuk mengetahui pengaruh citra merek dan kepercayaan merek terhadap loyalitas merek Sego Njamoer pada gerai Sego Njamoer Foodcourt Royal Plaza Surabaya. Menggunakan pendekatan kuantitatif. 70 responden pelanggan Sego Njamoer diambil sebagai sampel penelitian menggunakan teknik purposive sampling dari populasi pelanggan yang berkunjung di gerai Sego Njamoer Foodcourt Royal Plaza Surabaya. Pengolahan data dilakukan dengan teknik analisis PLS (Partial Least Square). Hasil penelitian menunjukan citra merek dan kepercayaan merek berpengaruh positif dan signifikan terhadap loyalitas merek Sego Njamoer pada gerai Sego Njamoer Foodcourt Royal Plaza Surabaya.
\end{abstract}

Kata Kunci: Citra merek, Kepercayaan merek, Loyalitas merek, Sego Njamoer

\section{ABSTRACT}

Sego Njamoer is the most popular brand of mushroom processed fast food in Surabaya which is experiencing a trend of fluctuating sales at the Foodcourt Royal Plaza Surabaya outlet. The fluctuation was due to the decline in customer brand loyalty in choosing and buying Sego Njamoer food. Purpose of this research to find the influence of brand image and brand trust on brand loyalty Sego Njamoer at the Sego Njamoer Foodcourt Royal Plaza Surabaya outlet. Using a quantitative approach. 70 respondents Sego Njamoer customers were taken as samples research using a purposive sampling technique from the customer population who visited the Sego Njamoer Foodcourt Royal Plaza Surabaya outlet. The data processing used PLS (Partial Least Square) analysis technique. Results of research showed brand image and brand trust had a positive and significant influence on brand loyalty Sego Njamoer at the Sego Njamoer Foodcourt Royal Plaza Surabaya outlet.

Keywords: Brand Image, Brand trust, Brand loyalty, Sego Njamoer 


\section{PENDAHULUAN}

Persaingan dalam bisnis makanan dan minuman (food and baverage) di Indonesia kian hari semakin kompetitif. Kementerian Perindustrian (2021), memaparkan data bahwa laju pertumbuhan di sektor industri makanan dan minuman sepanjang kurun waktu 2015-2019 rerata sebesar $8,16 \%$ diatas rerata pertumbuhan di sektor nonmigas. Perusahaan makanan dan minuman harus terus berkembang dan melakukan inovasi dalam rangka mempertahankan posisi persaingan. Salah satu unsur penting untuk mencapai tujuan tersebut adalah manajemen merek yang harus direncanakan dengan matang untuk memperkuat merek perusahaan. Merek yang cenderung kuat tidak akan mudah diintervensi oleh keberadaan merek lain walaupun banyak merek baru yang masuk kedalam pasar persaingan.

Sego Njamoer adalah merek makanan lokal yang populer dan mempunyai basis pelanggan yang besar terutama di kota Surabaya. Sego Njamoer merupakan waralaba dari CV. Sego Njamoer yang mulai berdiri pada tahun 2010. Produk mereka adalah produk makanan cepat saji (fast food) dengan jamur sebagai bahan baku utamanya. Hidangan lezat beragam olahan jamur seperti mealbox, jamur krispy, sosis jamur, kebab jamur dan lain-lain disajikan dalam bentuk kemasan makanan mobile packaging (take away) yang praktis dan kekinian. Produk-produk Sego Njamoer memiliki kualitas yang baik karena menggunakan bahan baku jamur segar dari petani lokal dan bumbu rempah-rempah pilihan.

Tercatat perusahaan tersebut memiliki 69 gerai yang saat ini tersebar di berbagai pusat perbelanjaan di wilayah Jawa. Peran aktif pemasaran perusahaan sangat penting untuk menangkap peluang pasar dan memberikan keluaran produk terbaru yang mampu bertahan dalam persaingan. Selain itu untuk menjaga eksistensi merek, Sego Njamoer harus memerhatikan loyalitas merek supaya pelanggan tidak berpindah ke merek produk kompetitor.

Berikut ini hasil penjualan makanan cepat saji Sego Njamoer gerai Foodcourt Royal Plaza Surabaya selama periode bulan Januari 2020 - Desember 2020.

Tabel 1. Penjualan Gerai Sego Njamoer Foodcourt Royal Plaza Surabaya

\begin{tabular}{lccc}
\hline \multirow{2}{*}{ Bulan } & \multicolumn{3}{c}{ Penjualan (Rp) } \\
\cline { 2 - 4 } & Tunai & Non Tunai & Total \\
\hline Januari & 43.279 .000 & 1.282 .000 & 44.561 .000 \\
Februari & 36.859 .000 & 1.673 .000 & 38.532 .000 \\
Maret & 25.123 .500 & 1.714 .500 & 26.838 .000 \\
April & 112.000 & - & 112.000 \\
Mei & 7.283 .000 & 385.000 & 7.668 .000 \\
Juni & 17.229 .000 & 2.271 .000 & 19.500 .000 \\
Juli & 22.308 .000 & 2.530 .000 & 24.838 .000 \\
Agustus & 28.991 .000 & 2.619 .000 & 31.610 .000 \\
September & 29.305 .000 & 2.505 .000 & 31.810 .000 \\
Oktober & 35.850 .000 & 2.185 .000 & 38.035 .000 \\
November & 35.850 .000 & 2.185 .000 & 38.035 .000 \\
Desember & 47.312 .500 & 15.887 .500 & 63.200 .000 \\
\hline
\end{tabular}

Sumber: Data perusahaan diolah 
Tabel 1 di atas menunjukkan tren penjualan pada salah satu gerai terbesar Sego Njamoer, terlihat bahwa perkembangan penjualan bulanan tidak stabil. Terjadi penurunan penjualan yang berturut-turut pada setiap bulannya dari bulan Januari sampai bulan April 2020. Sedangkan dari bulan Mei sampai bulan Desember 2020 penjualan gerai mulai mengalami peningkatan.

Turunnya komitmen pelanggan dalam memilih dan membeli makanan di Sego Njamoer mengakibatkan fluktuasinya penjualan. Hal tersebut mengindikasikan kurangnya tingkat loyalitas merek yang dimiliki pelanggan Sego Njamoer. Terdapat beberapa faktor yang berpotensi dapat memengaruhi turunnya loyalitas merek Sego Njamoer, faktor tersebut adalah citra merek dan kepercayaan merek. Meskipun perusahaan memiliki banyak pelanggan, akan tetapi citra merek Sego Njamoer tidak sepenuhnya menjadi top of mind yang mampu memotivasi pelanggan untuk senantiasa melangsungkan pembelian. Selain itu tidak sedikit dari pelanggan perusahaan suka berpindah-pindah merek karena kurangnya kepercayaan untuk menjalin hubungan jangka panjang dengan Sego Njamoer. Padahal, jika dilihat dari sisi perusahaan sudah meningkatkan aktivitas branding dan layanan pelanggan untuk memperkuat merek dan membangun hubungan yang lebih baik dengan pelanggan.

Loyal customer memilih suatu merek produk dalam jangka waktu lama dan tidak beralih ke merek produk lain menggambarkan sebuah ukuran loyalitas. Loyalitas merek penting membantu dalam membetuk basis pelanggan yang solid yang pada nantinya berfungsi sebagai alat bagi perusahaan untuk lebih unggul dari para pesaingnya dan sekaligus mencapai keunggulan kompetitif yang sangat dibutuhkan untuk survive dalam memimpin pasar. Loyal customer dari suatu merek tertentu akan kecil kemungkinannya untuk terpengaruhi upayaupaya pemasaran dari pesaing. Pelanggan yang loyal dapat menjadi duta merek bagi suatu perusahaan. Hal ini juga membuat konsumennya secara suka rela bersedia melakukan pemasaran dengan zero budget terkait produk atau jasa yang disukainya tersebut.

Sakinah \& Suhardi (2018), dalam penelitiannya menyatakan citra merek dan kepercayaan merek dapat memengaruhi loyalitas merek. Merek-merek dari satu kelompok pelayanan dengan kemiripan karakteristik menjadi peluang bagi kompetitor untuk meniru produk, sehingga perusahaan membutuhkan citra merek yang kuat untuk mempertahankan posisi di persaingan dan melindungi loyalitas merek. Loyalitas merek yang bagus timbul karena adanya citra positif merek dapat survive di tengah persaingan. Citra merek produk menjadi salah satu aspek penting untuk mewujudkan loyalitas merek (Sofyan, 2017). Kemudian aspek lain yang perlu diperhatikan adalah kepercayaan merek.

Konsumen yang percaya kepada merek akan mempunyai ekspektasi yang tinggi kepada perusahaan dengan keyakinan bahwa perusahaan akan memberikan hasil yang terbaik. Kepercayaan penting membantu konsumen dalam memangkas pengorbanan waktu, energi serta biaya atau kerugian lainnya yang mungkin saja konsumen alami apabila memilih untuk menggunakan suatu merek dikarenakan konsumen tidak memiliki pengalaman terhadap merek tertentu. Menurut Suntoro \& Silintowe (2020), untuk dapat membentuk loyalitas merek diperlukan kepercayaan merek yang kuat.

Berdasarkan pemaparan yang telah dikemukakan, tujuan penelitian ini adalah untuk mengetahui pengaruh citra merek dan kepercayaan merek terhadap loyalitas merek Sego Njamoer pada gerai Sego Njamoer Foodcourt Royal Plaza Surabaya. 


\section{KAJIAN PUSTAKA}

\subsection{Citra Merek}

Menurut Kurniawan (2017), citra merek merupakan persepsi seorang konsumen dalam memandang merek tertentu yang dibentuk berdasarkan pengetahuannya di masa lalu, sebagaimana tergambarkan dalam asosiasi merek yang tersimpan di ingatan konsumen. Gunadi et al. (2017), menjelaskan citra merek sebagai representasi asosiasi merek yang berhubungan dengan persepsi yang pertama kali diingat oleh konsumen terhadap suatu merek. Citra merek juga mengacu pada ingatan atau memori terkait suatu merek. Ingatan dan memori tersebut berisikan pemahaman konsumen akan suatu atribut, kelebihan, serta karakteristik perusahaan pemilik produk atau merek tersebut. Secara sederhana citra merek merupakan suatu pemahaman konsumen tentang apa yang dipikirkan serta dirasakan ketika melihat atau mendengar merek. Konsumen yang mempunyai citra positif dalam memandang satu merek akan lebih berpeluang untuk mengambil keputusan pembelian. Sebuah merek yang positif juga menjadi fondasi dalam membentuk reputasi perusahaan yang positif (Chalil et al., 2020). Merujuk kepada Sakinah \& Suhardi (2018), dalam penelitiannya penilaian citra merek dilakukan berdasarkan 3 pengukuran yaitu:

1. Strengthness, keunggulan sebuah merek produk yang didasarkan atas kekuatan yang melekat pada atribut fisik.

2. Uniqueness, nama sebuah merek mudah untuk diucapkan dan diingat oleh konsumen ataupun kesan unik atribut produk dimata konsumen yang menjadikannya berbeda dengan produk-produk sejenis.

3. Favorable, merek produk dikenal baik oleh konsumen dan menjadikannya merek favorit.

\subsection{Kepercayaan Merek}

Menurut Lau \& Lee dalam (Pertiwi et al., 2017), kepercayaan merek merupakan keyakinan atas harapan yang terbentuk di dalam benak konsumen dari kehandalan dan kemampuan merek dalam meyakinkan konsumen. Sari \& Widowati dalam (Putra \& Sulistyawati, 2019), mendefinisikan loyalitas merek sebagai kesediaan konsumen untuk mempercayai merek meskipun harus menerima semua risiko yang ada karena adanya harapan yang tinggi atas merek, oleh sebab itu konsumen akan berlangganan kepada merek. Kepercayaan pada merek mampu untuk memungkinkan konsumen mempersingkat waktu yang dibutuhkan dalam menentukan suatu keputusan pembelian. Dengan adanya kepercayaan terhadap suatu merek konsumen akan bersedia untuk memberikan rasa percayanya kepada perusahaan karena adanya keyakinan atas kinerja merek yang baik. Merujuk kepada Ika \& Kustini dalam (Suntoro \& Silintowe, 2020), penilaian kepercayaan merek dilakukan berdasarkan 2 dimensi yaitu:

1. Dimension of viability, persepsi yang mendefinisikan merek dapat memenuhi kebutuhan dan memuaskan seorang konsumen.

2. Dimension of intentionality, perasaan yang mendefinisikan keamanan dan kepercayaan konsumen atas merek. 


\subsection{Loyalitas Merek}

Menurut Kurniawan (2017), loyalitas merek merupakan inisiatif kesetiaan seorang konsumen terhadap satu merek yang membuatnya berkeinginan kuat untuk repeated purchase berulang kali secara konsisten. Rahayu \& Harsono (2017), menjelaskan loyalitas merek sebagai sebuah pilihan konsumen untuk senantiasa melakukan pembelian produk tertentu pada satu merek dari sebuah jenis pelayanan. Perusahaan yang loyalitas merek konsumennya cenderung kuat, akan memililki suatu basis pelanggan yang berkomitmen melakukan pembelian berulang atas produk dan layanan tertentu walaupun terjadi perubahan harga maupun kenyamanan atas produk atau layanan tersebut (Chalil et al., 2020). Oleh karena itu, dengan terus meningkatkan kepuasan konsumen, kemungkinan para pelanggan untuk terus menggunakan produk dan layanan dari perusahaan tertentu akan meningkat pula. Selain itu, perusahaan yang telah memiliki loyalitas merek yang kuat juga akan mengalami peningkatan basis pelanggannya. Merujuk kepada Sakinah \& Suhardi (2018), dalam penelitiannya penilaian loyalitas merek dilakukan berdasarkan 5 pengukuran yaitu:

1. Behavior measures, pengukuran kecenderungan seorang pelanggan untuk melangsungkan pembelian pada satu merek.

2. Measuring switching cost, pengukuran kemauan pelanggan untuk berkomitmen pada merek yang sama.

3. Measuring satisfaction, pengukuran kepuasan atau ketidakpuasan pelanggan atas kinerja merek produk.

4. Measuring liking the brand, pengukuran rasa suka pelanggan pada merek yang dicerminkan melalui kesediaannya untuk membayar harga lebih.

5. Measuring commitment, pengukuran komitmen pelanggan atas merek yang sampai pada tingkat membicarakan dan merekomendasikan merek kepada pihak lain.

\subsection{Pengaruh Citra Merek terhadap Loyalitas Merek}

Menurut Setiadi (2003), ketika seorang konsumen beranggapan satu merek tertentu mempunyai citra yang positif, maka akan lebih memungkinkan baginya untuk repeated purchase hingga pada fase loyal pada merek. Konsumen akan cenderung mengandalkan merek produk yang sudah memiliki citra yang baik sehingga konsumen berkeinginan untuk meneruskan pembeliannya (Novitasari \& Suryani, 2017). Penelitian sebelumnya yang mendukung hubungan citra merek dengan loyalitas merek, diantaranya adalah penelitian (Kurniawan, 2017; Sakinah \& Suhardi, 2018; Stefano \& Yuliawati, 2019) yang menemukan citra merek memiliki pengaruh positif dan signifikan terhadap loyalitas merek. Sehingga berikut ini hipotesis yang diajukan:

H1: Citra Merek berpengaruh positif dan signifikan terhadap Loyalitas Merek Sego Njamoer pada gerai Sego Njamoer Foodcourt Royal Plaza Surabaya.

\subsection{Pengaruh Kepercayaan Merek terhadap Loyalitas Merek}

Menurut Putra \& Sulistyawati (2019), kebiasaan pembelian ulang dan kesetiaan pelanggan terhadap sebuah merek didorong oleh rasa yakin dan percayanya kepada merek. 
Kepercayaan merek memberikan nilai kepada konsumen untuk setia membeli pada satu merek produk yang sama, konsumen yang puas akan kinerja merek akan berpotensi menjadi pelanggan loyal terhadap merek serta merekomendasikan kepada pihak lain (Rahayu \& Harsono, 2017). Penelitian sebelumnya yang mendukung hubungan kepercayaan merek dengan loyalitas merek, diantaranya adalah penelitian (Kurniawan, 2017; Suntoro \& Silintowe, 2020; Vernadila \& Realize, 2020) yang menemukan kepercayaan merek memiliki pengaruh positif dan signifikan terhadap loyalitas merek. Sehingga berikut ini hipotesis yang diajukan:

H2: Kepercayaan Merek berpengaruh positif dan signifikan terhadap Loyalitas Merek Sego Njamoer pada gerai Sego Njamoer Foodcourt Royal Plaza Surabaya.

\subsection{Kerangka Konseptual}

Alur pemikiran hubungan antar variabel citra merek, kepercayaan merek dan loyalitas merek digambarkan kedalam kerangka konseptual berikut:

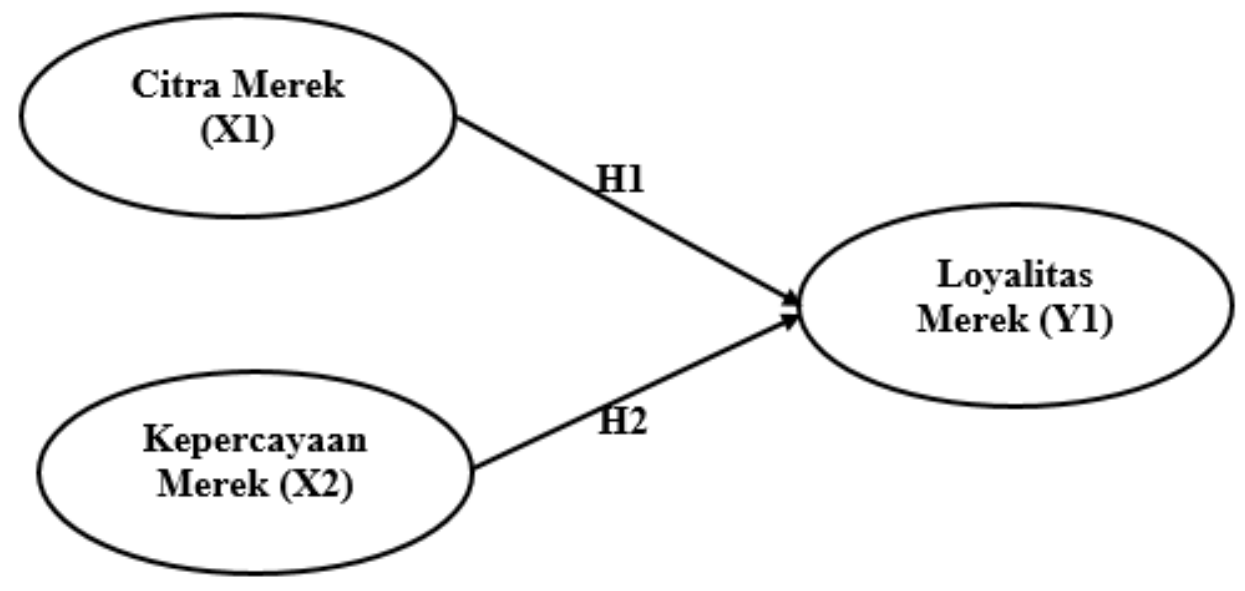

Gambar 1. Kerangka Konseptul

\section{METODE}

\subsection{Jenis Penelitian}

Penelitian ini menggunakan pendekatan kuantitaif. Jenis penelitian yang dilakukan adalah penelitian kausal yang bermaksud untuk mengetahui hubungan sebab-akibat antara variabel dalam penelitian.

\subsection{Definisi Operasional}

Definisi operasional variabel independen $(\mathrm{X})$ dan dependen $(\mathrm{Y})$ dalam studi ini meliputi sebagai berikut: 
Tabel 2. Operasionalisasi Variabel

\begin{tabular}{|c|c|c|c|c|c|}
\hline \multirow{2}{*}{$\begin{array}{l}\text { Variabel } \\
\text { Citra Merek } \\
\text { (X1) }\end{array}$} & \multirow{3}{*}{$\begin{array}{l}\text { Definisi Operasional } \\
\text { Persepsi yang ada diingatan } \\
\text { konsumen terhadap merek } \\
\text { yang dibentuk dari } \\
\text { informasi dan pengalaman } \\
\text { di masa lalu terhadap merek. }\end{array}$} & \multirow{2}{*}{$\begin{array}{l}\text { Dimensi } \\
\text { Strengthness }\end{array}$} & \multicolumn{3}{|c|}{ Indikator } \\
\hline & & & & $\mathrm{X} 1.1$ & $\begin{array}{l}\text { Kekuatan produk menjadi } \\
\text { keunggulan merek }\end{array}$ \\
\hline & & Uniqueness & & $\mathrm{X} 1.2$ & $\begin{array}{l}\text { Merek produk memiliki } \\
\text { bentuk yang unik }\end{array}$ \\
\hline & & $\begin{array}{l}\text { Favorable } \\
\text { (Sakinah }\end{array}$ & $\&$ & & $\begin{array}{l}\text { Nama merek mudah } \\
\text { diingat dan diucapkan }\end{array}$ \\
\hline & & Suhardi, 2018) & & $\mathrm{X} 1.4$ & $\begin{array}{l}\text { Merek produk menjadi } \\
\text { pilihan favorit }\end{array}$ \\
\hline
\end{tabular}

\begin{tabular}{|c|c|c|c|c|}
\hline \multirow[t]{4}{*}{$\begin{array}{l}\text { Kepercayaan } \\
\text { Merek (X2) }\end{array}$} & \multirow{4}{*}{$\begin{array}{l}\text { Kesediaan konsumen untuk } \\
\text { mengandalkan merek } \\
\text { dengan semua risiko yang } \\
\text { ada karena konsumen } \\
\text { memiliki keyakinan bahwa } \\
\text { merek tersebut tidak akan } \\
\text { mengecewakan. }\end{array}$} & \multirow[t]{2}{*}{$\begin{array}{l}\text { Dimension of } \\
\text { viability }\end{array}$} & $\mathrm{X} 2.1$ & $\begin{array}{l}\text { Merek produk dapat } \\
\text { memenuhi kebutuhan }\end{array}$ \\
\hline & & & $\mathrm{X} 2.2$ & $\begin{array}{l}\text { Merek produk tidak } \\
\text { mengecewakan }\end{array}$ \\
\hline & & $\begin{array}{l}\text { Dimension of } \\
\text { intentionality }\end{array}$ & $\mathrm{X} 2.3$ & $\begin{array}{l}\text { Merasa aman ketika } \\
\text { membeli merek produk }\end{array}$ \\
\hline & & $\begin{array}{l}\text { Ika \& Kustini } \\
\text { dalam (Suntoro \& } \\
\text { Silintowe, 2020) }\end{array}$ & $\mathrm{X} 2.4$ & $\begin{array}{l}\text { Merasa percaya ketika } \\
\text { membeli merek produk }\end{array}$ \\
\hline \multirow[t]{6}{*}{$\begin{array}{l}\text { Loyalitas } \\
\text { Merek (Y1) }\end{array}$} & $\begin{array}{l}\text { Kelekatan seorang } \\
\text { konsumen untuk setia } \\
\text { melangsungkan pembelian }\end{array}$ & Behavior measures & Y1.1 & $\begin{array}{l}\text { Membeli merek produk } \\
\text { secara berulang }\end{array}$ \\
\hline & $\begin{array}{l}\text { pada merek yang sama pada } \\
\text { saat sekarang dan masa } \\
\text { mendatang. }\end{array}$ & $\begin{array}{l}\text { Measuring } \\
\text { switching cost }\end{array}$ & Y1.2 & $\begin{array}{l}\text { Tidak tertarik berganti } \\
\text { merek lain }\end{array}$ \\
\hline & & $\begin{array}{l}\text { Measuring } \\
\text { satisfaction }\end{array}$ & Y1.3 & $\begin{array}{l}\text { Puas akan kualitas merek } \\
\text { produk }\end{array}$ \\
\hline & & $\begin{array}{l}\text { Measuring liking } \\
\text { the brand }\end{array}$ & Y1.4 & $\begin{array}{l}\text { Tetap membeli merek } \\
\text { produk meskipun harganya } \\
\text { naik }\end{array}$ \\
\hline & & \multirow{2}{*}{$\begin{array}{l}\text { Measuring } \\
\text { commitment } \\
\text { (Sakinah } \\
\text { Suhardi, 2018) }\end{array}$} & Y1.5 & $\begin{array}{l}\text { Membicarakan merek } \\
\text { kepada pihak lain }\end{array}$ \\
\hline & & & Y1.6 & $\begin{array}{l}\text { Merekomendasikan merek } \\
\text { kepada pihak lain }\end{array}$ \\
\hline
\end{tabular}

\subsection{Populasi dan Sampel}

Populasi penelitian ini adalah pelanggan yang berkunjung di gerai Sego Njamoer Foodcourt Royal Plaza Surabaya untuk membeli makanan dengan jumlah yang tidak diketahui. Sampel dari penelitian diambil menggunakan metode non probability sampling dan ditentukan dengan teknik purposive sampling. Kriteria sampel yang ditetapkan yaitu: (1) Usia minimal 17 
tahun, (2) Pelanggan Sego Njamoer yang pernah membeli makanan lebih dari 2 kali. Banyak sampel yang diambil sejumlah 70 responden mengacu kepada pedoman (Ghozali, 2011), yaitu 5-10 dikali total indikator.

\subsection{Jenis dan Sumber Data}

Penelitian ini menggunakan jenis data primer, diperoleh secara langsung dari responden individu yang membeli dan mengkonsumsi makanan cepat saji merek Sego Njamoer di gerai Sego Njamoer Foodcourt Royal Plaza Surabaya yang memenuhi syarat sampel yang telah ditetapkan. Instrumen yang dipakai untuk mengambil data dari responden adalah kuesioner dengan skala likert, kemudian data yang sudah didapat diolah dengan teknik analisis PLS (Partial Least Square).

\section{HASIL DAN PEMBAHASAN}

\subsection{Uji Outlier}

Tabel 3 menunjukkan kriteria uji outlier terpenuhi atau nilainya mahal karena diperoleh distance maximum data responden sebesar 28.410 dibawah nilai dari mahal distance maximum outlier yang ditetapkan sebesar 36.12327. Artinya tidak terdapat outlier di dalam data, sehingga data tersebut kualitasnya baik dan dapat dilanjutkan untuk pengolahan selanjutnya dengan banyak sampel 70 responden.

Tabel 3. Outlier Data

\begin{tabular}{lccccc}
\hline \multicolumn{7}{c}{ Residuals Statistics } & & & & \\
& Minimum & Maximum & Mean & $\begin{array}{c}\text { Std. } \\
\text { Deviation }\end{array}$ & N \\
\hline Predicted Value & 23.4161 & 48.2057 & 35.5000 & 5.99757 & 70 \\
\hline Std. Predicted Value & -2.015 & 2.118 & .000 & 1.000 & 70 \\
\hline Standard Error of Predicted Value & 5.196 & 14.217 & 9.800 & 2.391 & 70 \\
\hline Adjusted Predicted Value & 14.8156 & 64.3784 & 35.6477 & 8.91475 & 70 \\
\hline Residual & -36.88348 & 35.98759 & .00000 & 19.44726 & 70 \\
\hline Std. Residual & -1.693 & 1.652 & .000 & .893 & 70 \\
\hline Stud. Residual & -1.957 & 1.701 & -.003 & 1.012 & 70 \\
\hline Deleted Residual & -49.24425 & 44.18436 & -.14773 & 25.18358 & 70 \\
\hline Stud. Deleted Residual & -2.010 & 1.732 & -.003 & 1.018 & 70 \\
\hline Mahal. Distance & 2.941 & 28.410 & 13.800 & 6.686 & 70 \\
\hline Cook's Distance & .000 & .090 & .021 & .022 & 70 \\
\hline Centered Leverage Value & .043 & .412 & .200 & .097 & 70 \\
\hline
\end{tabular}

a. Dependent Variable: RESP

Sumber: Hasil olah data

Terdapat outlier apabila Mahal. Distance Maximum $>$ Prob. \& Jumlah variabel $[=\operatorname{CHIINV}(0,001 ; 14)$ : dicari melalui Excel] $=36.12327$

\subsection{Evaluasi Model Pengukuran}


Tabel 4 menunjukkan kriteria penilaian Convergen terpenuhi atau validitasnya baik karena keseluruhan nilai factor loading (original sample) indikator reflektif pada variabel Citra Merek (X1), Kepercayaan Merek (X2) dan Loyalitas Merek (Y1) di atas Z $\alpha=0,05$ (5\%) = 1,96 .

Tabel 4. Outer Loading

\begin{tabular}{ccc}
\hline Variabel & Indikator & Factor Loading (O) \\
\hline $\mathrm{X} 1$ & $\mathrm{X} 1.1$ & 0.800294 \\
& $\mathrm{X} 1.2$ & 0.826436 \\
& $\mathrm{X} 1.3$ & 0.552412 \\
& $\mathrm{X} 1.4$ & 0.721559 \\
\hline $\mathrm{X} 2$ & $\mathrm{X} 2.1$ & 0.853402 \\
& $\mathrm{X} 2.2$ & 0.907452 \\
& $\mathrm{X} 2.3$ & 0.931778 \\
& $\mathrm{X} 2.4$ & 0.922661 \\
\hline $\mathrm{Y} 1$ & $\mathrm{Y} 1.1$ & 0.675273 \\
& $\mathrm{Y} 1.2$ & 0.804839 \\
& $\mathrm{Y} 1.3$ & 0.821536 \\
& $\mathrm{Y} 1.4$ & 0.771840 \\
& $\mathrm{Y} 1.5$ & 0.696737 \\
& $\mathrm{Y} 1.6$ & 0.800501 \\
\hline
\end{tabular}

Sumber: Hasil olah data

Tabel

5 menunjukkan pengukuran data cross loading kriteria Discriminant terpenuhi atau validitasnya baik karena keseluruhan nilai cross loading indikator reflektif pada variabel Citra Merek (X1), Kepercayaan Merek (X2) dan Loyalitas Merek (Y1) pada model penelitian ini memiliki nilai terbesar dari pada cross loading indikator variabel lain.

Tabel 5. Cross Loading

\begin{tabular}{ccccc}
\hline \multirow{2}{*}{ Variabel } & \multirow{2}{*}{ Indikator } & \multicolumn{3}{c}{ Cross Loading } \\
\cline { 3 - 5 } & & $\mathbf{X 1}$ & $\mathbf{X} 2$ & Y1 \\
\hline $\mathrm{X} 1$ & $\mathrm{X} 1.1$ & 0.800294 & & \\
& $\mathrm{X} 1.2$ & 0.826436 & & \\
$\mathrm{X} 1.3$ & 0.552412 & & \\
& $\mathrm{X} 1.4$ & 0.721559 & & \\
\hline $\mathrm{X} 2$ & $\mathrm{X} 2.1$ & & 0.853402 & \\
& $\mathrm{X} 2.2$ & & 0.907452 & \\
& $\mathrm{X} 2.3$ & & 0.931778 & \\
& $\mathrm{X} 2.4$ & & 0.922661 & \\
\hline $\mathrm{Y} 1$ & $\mathrm{Y} 1.1$ & & & 0.675273 \\
& $\mathrm{Y} 1.2$ & & & 0.804839 \\
& $\mathrm{Y} 1.3$ & & & 0.771840 \\
& $\mathrm{Y} 1.4$ & & 0.696737 \\
& $\mathrm{Y} 1.5$ & & 0.800501 \\
\hline
\end{tabular}

Sumber: Hasil olah data 
Selain dilihat melalui outer loading dan cross loading, dapat pula diketahui melalui pengukuran Avarage Variance Extracted (AVE). Tabel 6 menunjukan hasil pengujian AVE dalam model penelitian. Variabel Citra Merek (X1) menunjukkan nilai AVE sebesar 0.537318,

Tabel 6. Average Variance Extracted (AVE)

\begin{tabular}{cc}
\hline Variabel & AVE \\
\hline $\mathrm{X} 1$ & 0.537318 \\
$\mathrm{X} 2$ & 0.817819 \\
$\mathrm{Y} 1$ & 0.583444 \\
\hline
\end{tabular}

Sumber: Hasil olah data

Kepercayaan Merek (X2) sebesar 0,817819, dan Loyalitas Merek (Y1) sebesar 0,583444 . Secara keseluruhan ketiga variabel penelitian ini dapat dikatakan validitasnya baik karena telah terpenuhinya kriteria penilaian AVE di atas 0,50.

Tabel 7 menunjukkan pengujian Composite Reliability seluruh variabel mempunyai nilai lebih dari 0,70 artinya seluruh variabel pada penelitian ini reliabel. Variabel Citra Merek (X1) menunjukkan nilai sebesar 0.819701, Kepercayaan Merek (X2) sebesar 0.947190, dan Loyalitas Merek sebesar (Y1) 0.893149.

Tabel 7. Composite Reliability

\begin{tabular}{cccc}
\hline Variabel & Composite Reliability & Cut Point & Keterangan \\
\hline X1 & 0.819701 & 0,7 & Reliabel \\
X2 & 0.947190 & 0,7 & Reliabel \\
Y1 & 0.893149 & 0,7 & Reliabel \\
\hline
\end{tabular}

Sumber: Hasil olah data

Tabel 8 menunjukkan latent variabel correlations pada model penelitian mempunyai nilai korelasi rata-rata di atas 0,5 dari hubungan antar variabel dari penelitian ini. Terlihat nilai korelasi tertinggi sebesar 0.791014 terdapat pada hubungan Kepercayaan Merek (X2) dengan Loyalitas Merek (Y1). Artinya ditemukan korelasi yang lebih kuat antara kedua variabel tersebut dibandingkan dengan hubungan Citra Merek (X1) dengan Loyalitas Merek (Y1) yang ada didalam model penelitian. Selain itu dapat juga didefinisikan tinggi atau rendahnya loyalitas merek dalam model penelitian paling banyak mendapat pengaruh dari variabel kepercayaan merek.

Tabel 8. Latent Variable Correlations

\begin{tabular}{cccc}
\hline Variabel & Xl & X2 & Y1 \\
\hline $\mathrm{X} 1$ & 1.000000 & & \\
$\mathrm{X} 2$ & 0.791014 & 1.000000 & \\
$\mathrm{Y} 1$ & 0.705821 & 0.710647 & 1.000000 \\
\hline
\end{tabular}

Sumber: Hasil olah data 


\subsection{Evaluasi Model Struktural}

Nilai R-Square dalam model penelitian menjadi acuan untuk pengujian terhadap model struktural. Terlihat dari tabel 9 nilai $\mathrm{R}^{2}=0,560180$. Nilai tersebut dapat didefinisikan bahwa variabel Loyalitas Merek (Y1) yang dipengaruhi oleh variabel independen antara lain Citra Merek (X1) dan Kepercayaan Merek (X2) mempunyai varian sebesar 56,01\%, sisannya sebesar 43,99\% dijelaskan oleh variabel lain yang tidak dimasukkan dalam penelitian.

Tabel 9. R Square

\begin{tabular}{ll}
\hline & R Square \\
\hline $\mathrm{X} 1$ & \\
$\mathrm{X} 2$ & \\
$\mathrm{Y} 1$ & 0.560180 \\
\hline
\end{tabular}

Sumber: Hasil olah data

\subsection{Pengujian Hipotesis}

Pengujian hipotesis dapat diketahui melalui nilai koefisien dan T-statistic dibawah ini:

Tabel 10. Pengujian Signifikansi

\begin{tabular}{lccccc}
\hline \multirow{2}{*}{ Variabel } & \multirow{2}{*}{ Path Coefficients } & \multicolumn{4}{c}{ Pengujian Signifikansi } \\
\cline { 3 - 5 } & & T Statistics & & Cut Off & Hasil \\
\hline X1 - Y1 & 0.383890 & 3.805330 & $>$ & 1,96 & Signifikan \\
X2 - Y1 & 0.406984 & 4.129479 & $>$ & 1,96 & Signifikan \\
\hline
\end{tabular}

Sumber: Hasil olah data

Berdasarkan dari tabel 10 pengujian signifikansi, dapat ditarik sebuah kesimpulan penelitian yang menyatakan bahwa hipotesis:

1. Citra Merek (X1) berpengaruh positif terhadap Loyalitas Merek (Y1) dapat diterima, kriteria penilaian signifikansi terpenuhi atau signifikan (positif) karena diperoleh nilai path coefficients 0.383890 dan T-statistic 3.805330, hasil tersebut menunjukkan nilai di atas $\mathrm{Z} \alpha=0,05(5 \%)=1,96$.

2. Kepercayaan Merek (X2) berpengaruh positif terhadap Loyalitas Merek (Y1) dapat diterima, kriteria penilaian signifikansi terpenuhi atau signifikan (positif) karena diperoleh nilai path coefficients 0.406984 dan T-statistic 4.129479 , hasil tersebut menunjukkan nilai di atas $\mathrm{Z} \alpha=0,05(5 \%)=1,96$. 
Sebagaimana gambar 2 output smartPLS dengan bootstrapping menunjukkan signifikansi hasil nilai T-Statistic.

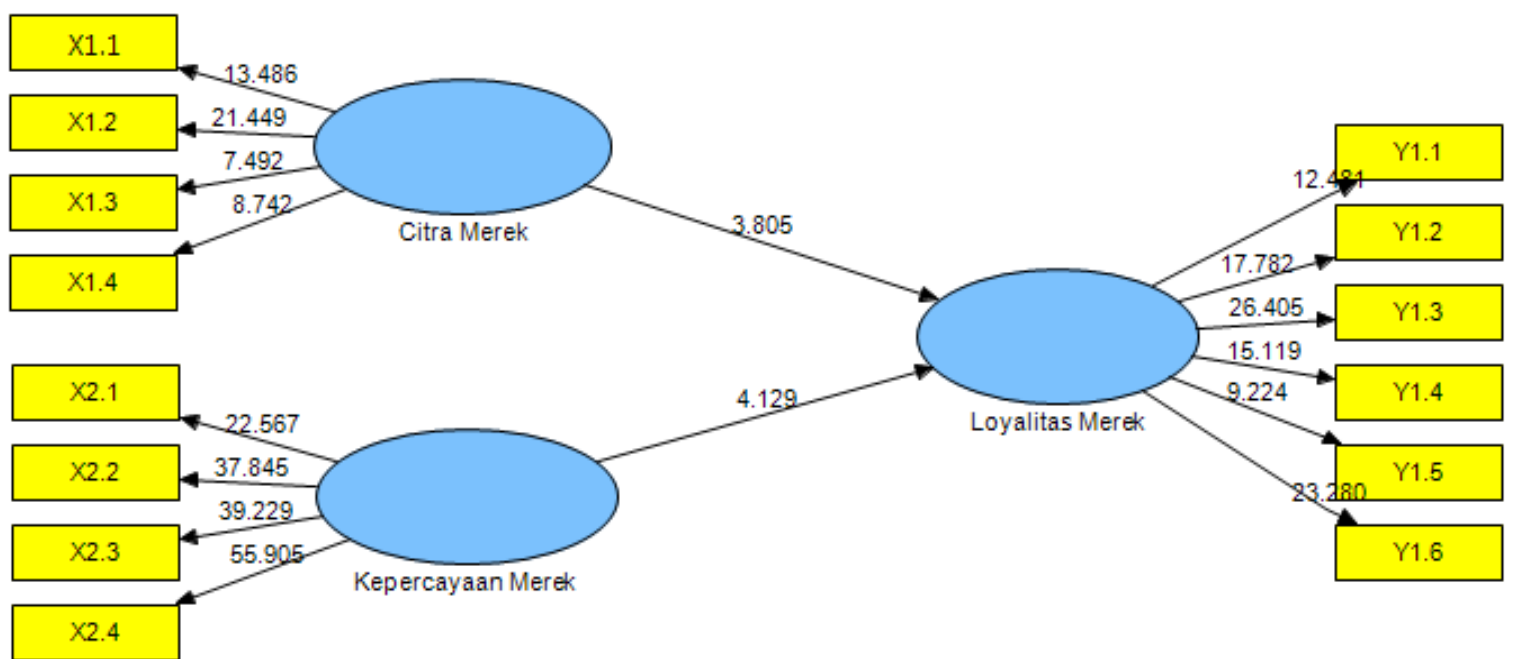

Gambar 2. Inner Model dengan nilai signifikansi T-Statistic

Sumber: Hasil olah data

Berdasarkan gambar 3, di atas tanda panah antara variabel dan indikator terlihat besarnya nilai factor loading setiap indikator, di atas garis panah antara variabel eksogen terhadap variabel endogen juga terlihat besarnya path coefficient. Sedangkan besarnya nilai $R$-square terlihat di dalam lingkaran variabel endogen (Loyalitas Merek).

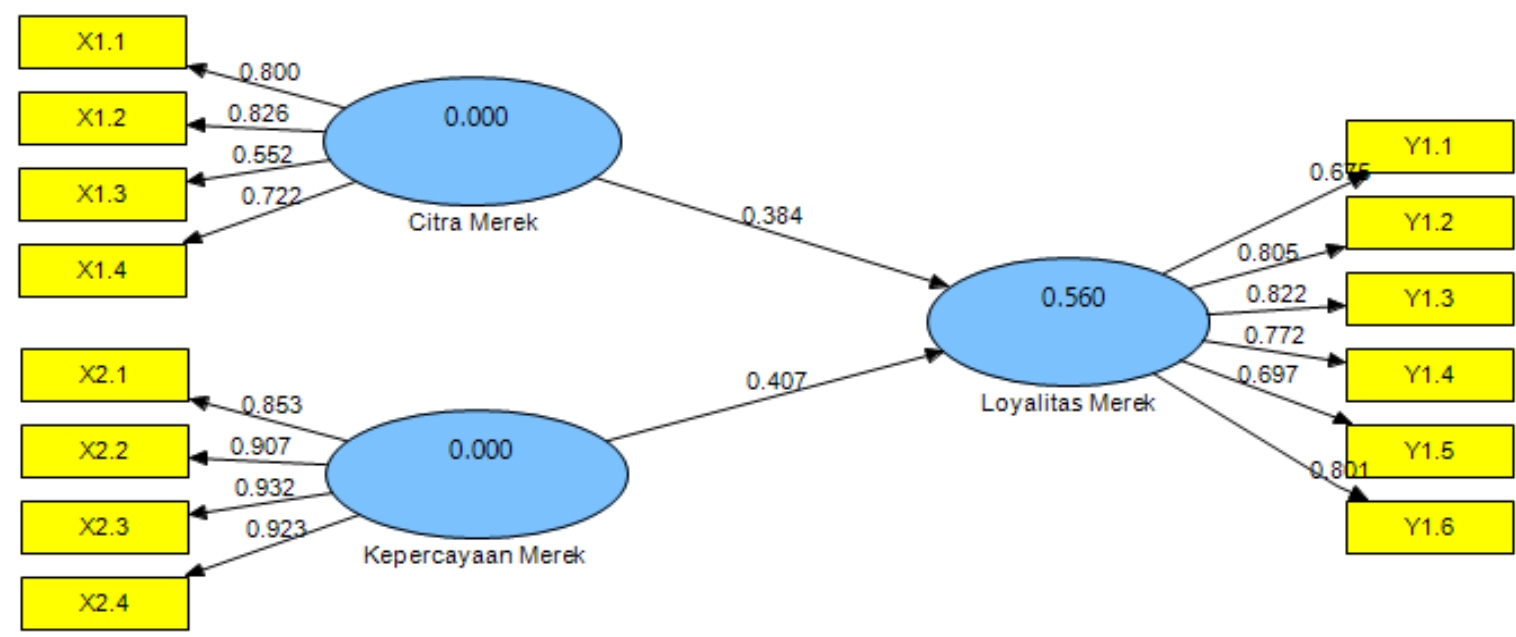

Gambar 3. Outer Model dengan Path Coefficient

Sumber: Hasil olah data 


\subsection{Pengaruh Citra Merek (X1) Terhadap Loyalitas Merek (Y1)}

Citra Merek (X1) pada penelitian ini terbukti berpengaruh positif dan signifikan terhadap Loyalitas Merek (Y1) dengan path coefficients 0.383890 dan T-statistic 3.805330 di atas nilai $\mathrm{Z} \alpha=0,05(5 \%)=1$,96. Artinya, semakin kuat citra merek Sego Njamoer dimata pelanggan maka akan membentuk loyalitas merek Sego Njamoer pada gerai Foodcourt Royal Plaza Surabaya. Temuan ini sejalan dengan penelitian (Kurniawan, 2017; Putra \& Sulistyawati, 2019; Sakinah \& Suhardi, 2018; Stefano \& Yuliawati, 2019; Vernadila \& Realize, 2020) yang membuktikan citra merek berpengaruh positif dan signifikan terhadap loyalitas merek. Ditinjau dari nilai loading factor yang tertinggi (0.826436), variabel citra merek terutama dibentuk oleh indikator X1.2 yaitu "merek produk memiliki bentuk yang unik". Temuan tersebut menunjukkan bahwa kemampuan perusahaan untuk membuat desain produk yang futuristik dan berbeda dari kompetitor sangat penting untuk meningkatkan citra positif merek. Citra suatu merek akan memengaruhi dan meningkatkan motivasi pelanggan untuk tetap melangsungkan pembelian suatu merek produk. Adanya citra merek positif akan menguntungkan perusahaan dalam menjaring pelanggan baru dan mempertahankan loyalitas merek yang sudah ada.

\subsection{Pengaruh Kepercayaan Merek (X2) Terhadap Loyalitas Merek (Y1)}

Kepercayaan Merek (X2) pada penelitian ini terbukti berpengaruh positif dan signifikan terhadap Loyalitas Merek (Y1) dengan path coefficients 0.406984 dan T-statistic 4.129479 di atas nilai $\mathrm{Z} \alpha=0,05(5 \%)=1,96$. Artinya, semakin kuat kepercayaan merek pelanggan Sego Njamoer maka akan membentuk loyalitas merek Sego Njamoer pada gerai Foodcourt Royal Plaza Surabaya. Temuan ini sejalan dengan penelitian (Kurniawan, 2017; Putra \& Sulistyawati, 2019; Stefano \& Yuliawati, 2019; Suntoro \& Silintowe, 2020; Vernadila \& Realize, 2020) yang membuktikan kepercayaan merek berpengaruh positif dan signifikan terhadap loyalitas merek. Indikator X2.3 dari variabel kepercayaan merek yaitu "merasa aman ketika membeli merek produk" merupakan komponen penting untuk membangun kepercayaan merek dengan nilai loading factor tertinggi (0.931778). Kemampuan perusahaan untuk mengedukasi pelanggan bahwa perusahaan menghasilkan produk yang sehat dan bergizi menentukan pencapaian kepercayaan merek lebih tinggi. Rasa percaya pelanggan pada merek akan mampu memunculkan hubungan baik dengan merek sehingga menghasilkan sebuah komitmen, oleh karenannya pelanggan akan setia dan enggan untuk beralih merek.

\section{KESIMPULAN}

\subsection{Kesimpulan}

1. Citra Merek (X1) memiliki kontribusi terhadap Loyalitas Merek (Y1). Hal ini dapat diartikan bahwa citra merek yang baik mampu mendorong pelanggan untuk senantiasa berlangganan pada merek makanan cepat saji Sego Njamoer pada gerai Sego Njamoer Foodcourt Royal Plaza Surabaya.

2. Kepercayaan Merek (X1) memiliki kontribusi terhadap Loyalitas Merek (Y1). Hal ini dapat diartikan bahwa kepercayaan merek yang baik mampu mendorong pelanggan 
untuk senantiasa berlangganan pada merek makanan cepat saji Sego Njamoer pada gerai Sego Njamoer Foodcourt Royal Plaza Surabaya.

\subsection{Saran}

1. Kepada perusahaan diharapkan dapat meningkatkan keunikan produk Sego Njamoer. Perusahaan dirasa perlu membuat desain packaging Sego Njamoer yang lebih unik agar produk Sego Njamoer mudah dikenali diantara merek lainnya untuk kategori makanan cepat saji dalam kemasan mobile packaging (take away).

2. Kepada perusahaan diharapkan dapat meningkatkan keamanan produk Sego Njamoer. Perusahaan dirasa perlu mempromosikan merek Sego Njamoer melalui iklan hijau agar produk Sego Njamoer mendapat kepercayaan penuh dari semua pelanggan.

\section{REFERENSI}

Chalil, R. D., Sari, J. D. P., Bus, M., Ulya, Z., \& Hamid, A. (2020). Brand, Islamic Branding, \& Rebranding. PT. Raja Grafindo.

Ghozali, I. (2011). Aplikasi Analisis Multivariate Dengan Program SPSS. Badan Penerbit Universitas Diponegoro.

Gunadi, F. A., Adiwijaya, M., \& Subagio, H. (2017). Pengaruh Perceived Quality Terhadap Brand Loyalty dengan Brand Image dan Brand Trust sebagai Variabel Intervening pada Merek Laptop Buatan Indonesia. Petra Business and Management Review, 3(2), 84-105.

Kementerian Perindustrian. (2021). Industri Makanan dan Minuman Diakselerasi Menuju Transformasi Digital. Kemenperin.Go.Id. https://kemenperin.go.id/artike1/22485/IndustriMakanan-dan-Minuman-Diakselerasi-Menuju-Transformasi-Digital

Kurniawan, H. H. (2017). Pengaruh Perceived Quality Terhadap Brand Loyalty Melalui Mediasi Brand Image dan Brand Trust. Jurnal Bisnis Dan Manajemen, 4(2), 228-239.

Novitasari, A., \& Suryani, T. (2017). Peran Kepercayaan Merek, Citra Merek, dan Celebrity Endorsement Terhadap Loyalitas Merek Bedak Tabur Wardah. Journal of Business \& Banking, 7(2), 251-262.

Pertiwi, A. R., Djawahir, A. H., \& Andarwati. (2017). Pengaruh Brand Experience Terhadap Brand Satisfaction, Brand Trust dan Brand Loyalty (Studi pada Konsumen Make-Up Brand Impor di Surabaya). Jurnal Manajemen Dan Kewirausahaan, 5(2), 20-35.

Putra, I. W. G. G., \& Sulistyawati, E. (2019). Peran Band Trust Memediasi Pengaruh Brand Image Terhadap Brand Loyalty. E-Jurnal Manajemen, 8(7), 4328-4356.

Rahayu, S., \& Harsono, M. (2017). Kepercayaan Merek dan Brand Affect sebagai Anteseden dari Loyalitas Merek. Jurnal Manajemen Dan Bisnis Media Ekonomi, XVII(1), 9-22. 
Sakinah, N. L., \& Suhardi, D. (2018). Citra Merek, Kepercayaan Merek dalam Mewujudkan Loyalitas Merek Produk Aqua. Indonesian Journal of Strategic Management, 1(1), 13-31.

Setiadi, N. J. (2003). Perilaku Konsumen Konsep dan Implikasi untuk Strategi Penelitian Pemasaran. Kencana.

Sofyan, M. (2017). Pengaruh CSR perusahaan terhadap citra merek dan loyalitas merek. Jurnal Siasat Bisnis, 21(1), 1-18.

Stefano, B. A., \& Yuliawati. (2019). Analisis Determinan Brand Loyalty Singkong Keju D-9. Jurnal Riset Manajemen Sains Indonesia, 10(2), 247-266.

Suntoro, W., \& Silintowe, Y. B. R. (2020). Analisis Pengaruh Pengalaman Merek, Kepercayaan Merek, dan Kepuasan Merek Terhadap Loyalitas Merek. Jurnal Modus, 32(1), 25-41.

Vernadila, R. Y., \& Realize. (2020). Pengaruh Kepercayaan Merek, Citra Merek dan Persepsi Kualitas Terhadap Loyalitas Merek Sensodyne. Jurnal Ilmiah Mahasiswa Ekonomi Manajemen, 5(3), 633-646. 